\title{
6-Azido- and 6-Aminoflavins as Active-Site Probes of Flavin Enzymes ${ }^{\dagger}$
}

\author{
Vincent Massey,*, Sandro Ghisla, ${ }^{\S}$ and Kunio Yagi \\ Institute of Applied Biochemistry, Yagi Memorial Park, Mitake, Gifu 505-01, Japan \\ Received May 5, 1986; Revised Manuscript Received August 1, 1986
}

\begin{abstract}
Azidoflavins have been bound to the apoproteins of five representative flavoproteins and their properties, before and after light irradiation, compared with those of the same proteins containing the appropriate 6-aminoflavin. In the dark the 6-azidoflavoproteins are quite stable, except for L-lactate oxidase, where spontaneous conversion to the 6-amino-FMN enzyme occurs slowly at $\mathrm{pH}$ 7. 6-Azido-FMN Old Yellow Enzyme is converted to the 6-amino-FMN enzyme by aerobic turnover with NADPH, and 6azido-FAD D-amino acid oxidase is converted to the 6-amino-FAD enzyme by treatment with $D$-alanine. Light irradiation of 6-azidoriboflavin bound to riboflavin-binding protein does not result in any covalent fixation of the flavin to the protein. Light irradiation of 6-azido-FMN flavodoxin gives only a sma'l amount of covalent linkage. In contrast, 6-azido-FMN Old Yellow Enzyme undergoes a very facile light-induced change, in which approximately $50 \%$ of the flavin is attached in a stable covalent linkage to the protein. The resulting flavoprotein form has lost the ability to bind phenols, a distinctive characteristic of the native enzyme; it does, however, bind NADPH, but the latter cannot reduce the covalently bound flavin. 6Azido-FAD D-amino acid oxidase also undergoes a facile light modification, in which almost quantitative fixation of the flavin to the protein takes place. The resulting flavoprotein cannot bind benzoate, an active-site ligand for the native enzyme, nor is it reduced anaerobically by D-alanine. The covalent linkage is fairly labile and is destroyed on denaturation of the protein. 6-Azido-FMN lactate oxidase is also fairly susceptible to light irradiation; in this case, however, much of the change occurs in a dark reaction following irradiation. The product is readily reduced by L-lactate, in contrast to the results with D-amino acid oxidase. We have not yet been able to determine whether a covalent linkage occurs, although the evidence implies that a labile covalent linkage is formed, which is probably hydrolyzed in a subsequent dark reaction.
\end{abstract}

O ne of the great advantages of working with flavoproteins is the ease with which, in general, the natural flavin coenzyme may be removed under relatively mild conditions and the resulting inactive apoprotein reconstituted either with the natural coenzyme, FAD or FMN, ${ }^{1}$ or with flavin derivatives carrying the appropriate $\mathrm{N}(10)$-substituent. The ability to bind modified flavins seems to arise from the dominant binding forces between apoprotein and the flavin $N(10)$ side chain, although binding energy must also be derived from interactions between the protein and the isoalloxazine ring system. Indeed, specific hydrogen bonds between protein and the oxidized flavin positions $2,3,4$, and 5 are theoretically possible [see Nishimoto et al. (1978) and Massey and Ghisla (1983) for a discussion], and some of these appear to be present as judged from the X-ray crystallographic studies of flavodoxin (Burnett et al., 1979), and glutathione reductase (Schulz et al., 1982). Such interactions can also be investigated by techniques such as NMR (Beinert et al., 1985) and resonance Raman spectroscopy (Kitagawa et al., 1979).

Information from all these techniques, however, involves either very considerable effort in time or very considerable amounts of protein required for the measurements. A valuable supplement to these methods, which requires much less time and only small amounts of protein, is the replacement of the native flavin by modified flavins [see Massey and Hemmerich

\footnotetext{
${ }^{\dagger}$ This work was supported in part by a grant from the Deutsche Forschungsgemeinschaft (Gh 2/4-4) to S.G., a grant from the U.S. Public Health Service (GM 11106), and sabbatical support from the Alexander von Humboldt Stiftung to V.M.

tPresent address: Department of Biological Chemistry, University of Michigan, Ann Arbor, MI 48109.

Present address: Fakultät für Biologie, Universität Konstanz, D-7750 Konstanz, FRG.
}

(1980) for a review]. Such active-site probes can be classified into four broad categories on the basis of thei: chemical properties. First, there are flavin analogues that give information by virtue of spectral effects induced on binding. Examples of this class are 6-hydroxyflavins (Mayhew et al., 1974), 8-hydroxyflavins (Ghisla \& Mayhew, 1976), and 8mercaptoflavins (Massey et al., 1979), which all give information concerning the electrostatic or solvent nature of the flavin binding site. The second class consists of flavins with chemically reactive substituents, which react either with a protein functional group at the active site or with solvent-borne reactants. Examples of this class are 8-chloro- (Moore et al., 1979; Schopfer et al., 1981) or 8-fluoroflavins (Kasai et al., 1983), 8-mercaptoflavins (Massey et al., 1979), 2-thioflavins (Biemann et al., 1983; Claiborne et al., 1982), 4-thioflavins (Massey et al., 1984a,b), and 5-deazaflavins (Vargo et al., 1981). A third class, which can be defined loosely as mechanism probes and which can involve members of any of the other classes as well, relies largely on the oxidation-reduction potential of the flavin derivative (Abramovitz \& Massey, 1976; Light \& Walsh, 1980; Stewart \& Massey, 1985; Hille et al., 1981 ) or on the substitution of carbon for nitrogen at the flavin positions 5 or 1 (Edmonson et al., 1972; Jorns \& Hersh, 1975; Fisher et al., 1976; Spencer et al., 1977). Finally, we have the so far very small class of photoaffinity flavins. The first of these carried an azido function in the adenine moiety of FAD (Koberstein, 1976) and thus is not expected to give information on the immediate environment of the isoalloxazine ring system, since the available X-ray crystallographic data

\footnotetext{
${ }^{1}$ Abbreviations: FAD, flavin adenine dinucleotide; FMN, flavin mononucleotide; $\mathrm{NADP}^{+}$, nicotinamide adenine dinucleotide phosphate; NADPH, reduced nicotinamide adenine dinucleotide phosphate; HPLC, high-performance liquid chromatography.
} 
show that FAD appears to bind to flavoproteins in the extended configuration (Schulz et al., 1982; Wierenga et al., 1979; Karplus \& Herriott, 1982). Recently we have reported studies with 8-azidoflavoproteins (Fitzpatrick et al., 1985), and in the previous paper in this series we have reported the synthesis and some properties of 6-azidoflavins (Ghisla et al., 1986). The availability of a chemically reactive and photoreactive substituent at the flavin 6-position was of interest in terms of expanding information on the protein environment around this position, by virtue of its proximity to the catalytically important $\mathrm{N}$ (5)-position. In this paper we report results obtained with five representative flavoproteins substituted with the potential photolabel 6-azidoflavin and compare their properties with the same proteins substituted with 6-aminoflavins.

\section{ExPerimental Procedures}

Materials. The flavin derivatives and apoproteins used were obtained as described in a previous paper (Ghisla et al., 1986). $\mathrm{NADP}^{+}$, glucose 6-phosphate, and glucose-6-phosphate dehydrogenase were from Sigma Chemical Co., St. Louis. Phenol, $p$-chlorophenol, and $p$-nitrophenol were from Nakarai Chemicals, Kyoto.

Instrumentation. Absorption spectra were recorded with a Shimadzu UV-250 spectrophotometer at $20^{\circ} \mathrm{C}$, when not otherwise indicated. HPLC analysis was done with a Shimadzu LC-4A instrument using a Develosil $(30 \times 0.7 \mathrm{~cm})$ $\mathrm{RP}_{18}$ column and the elution conditions given previously (Ghisla et al., 1986). Alternatively, where noted, elution was carried out at $40{ }^{\circ} \mathrm{C}$ with isocratic systems of 30 parts methanol/70 parts $0.01 \mathrm{M}$ phosphate $(\mathrm{pH} 6.0)$ or 20 parts methanol/80 parts $0.01 \mathrm{M}$ phosphate ( $\mathrm{pH} 6.0$ ).

Light irradiation of 6- $\mathrm{N}_{3}$-flavins bound to specific flavoproteins was carried out essentially as described previously (Fitzpatrick et al., 1985). The samples were irradiated with a commercial "sun gun" with intensity controlled by a rheostat, and the samples were held in a Pyrex glass bath, with temperature maintained at $20^{\circ} \mathrm{C}$ by periodic addition of crushed ice. As the Pyrex glass cuts off light of wavelengths lower than $320 \mathrm{~nm}$, the photochemical events that occur come from excitation of the flavin chromophore not the protein.

\section{RESULTS AND DISCUSSION}

Binding of 6-Aminoriboflavin and 6-Azidoriboflavin to Riboflavin-Binding Protein and Effect of Light. 6-Azidoriboflavin binds tightly to the apoprotein of hen egg white riboflavin-binding protein, with a $K_{\mathrm{d}}$ value of $10^{-8} \mathrm{M}$ at $\mathrm{pH}$ $7.0,20^{\circ} \mathrm{C}$ (Figure 1). By standardization of the apoprotein with pure riboflavin, one can then determine the extinction coefficients of both the free and the protein-bound 6- $\mathrm{N}_{3}$ riboflavin. As shown in Figure 1, the free flavin has a $\lambda_{\max }$ at $423 \mathrm{~nm}$ and an extinction coefficient of $19000 \mathrm{M}^{-1} \mathrm{~cm}^{-1}$. When it binds to riboflavin-binding protein, the $\lambda_{\max }$ shifts to $432 \mathrm{~nm}$ and the extinction coefficient falls to $15100 \mathrm{M}^{-1} \mathrm{~cm}^{-1}$. Similar shifts in $\lambda_{\max }$ and decreases in extinction coefficient are features common to the binding of all flavins to this protein (Choi \& McCormick, 1980). Similar results were obtained with 6- $\mathrm{NH}_{2}$-riboflavin $\left(\lambda_{\max } 428 \mathrm{~nm}, \epsilon=18000 \mathrm{M}^{-1} \mathrm{~cm}^{-1}\right)$, which exhibits shifts on binding to a $\lambda_{\max }$ of $439 \mathrm{~nm}$ and $\epsilon=$ $14500 \mathrm{M}^{-1} \mathrm{~cm}^{-1}$ (results not shown). These results indicate that the flavin binding site of this protein is able to accomodate fairly bulky substituents at the flavin 6-position without any obvious change in the general properties of the flavoprotein. This conclusion is further substantiated by the tight binding of 6-thiocyanato- and 6-mercaptoriboflavin, as will be documented in the following paper (Massey et al., 1986). It should also be noted that these results are consistent with the finding

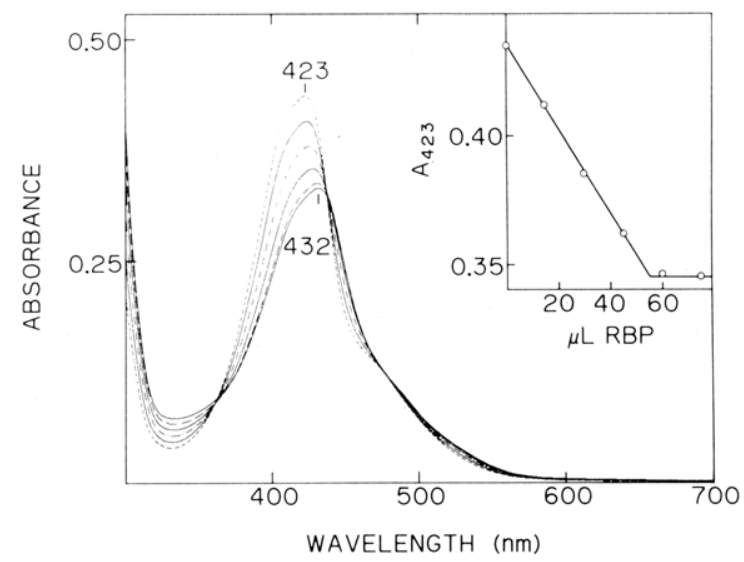

FIGURE 1: Titration of 6-azidoriboflavin with the apoprotein of hen egg white riboflavin-binding protein. A $1.0-\mathrm{mL}$ sample of $6-\mathrm{N}_{3}$ riboflavin in $0.05 \mathrm{M}$ potassium phosphate buffer $(\mathrm{pH} 7.0)$ at $20^{\circ} \mathrm{C}$ (top curve with $\lambda_{\max } 423 \mathrm{~nm}$ ) was titrated with $15-\mu \mathrm{L}$ aliquots of riboflavin-binding protein (succeeding curves). The concentration of the protein was determined in a similar experiment by titration of pure riboflavin and found to be $4.09 \times 10^{-4} \mathrm{M}$. The inset shows the $A_{423}$, corrected for dilution, vs. the volume of riboflavin-binding protein added. From this it is clear that binding is very tight, with an upper limit for $K_{\mathrm{d}}$ of $10^{-8} \mathrm{M}$. From the end point, and the known concentration of the riboflavin-binding protein, $\epsilon_{423}$ of free $6-\mathrm{N}_{3}$ riboflavin can be calculated to be $19000 \mathrm{M}^{-1} \mathrm{~cm}^{-1}$.

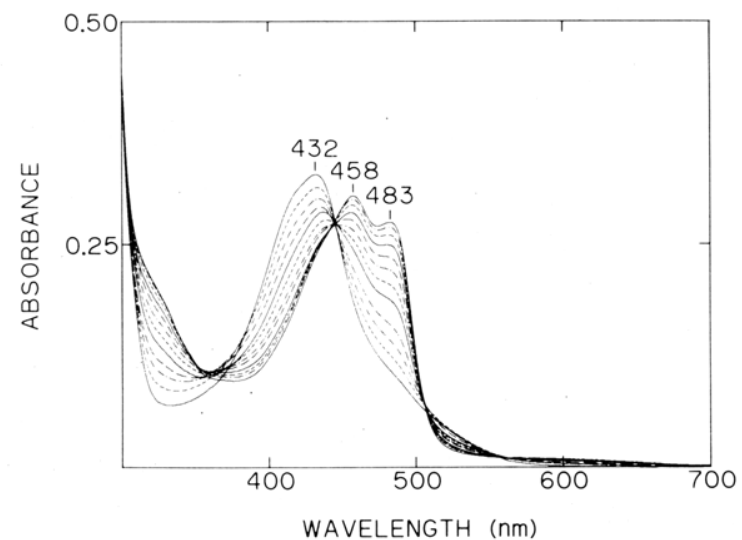

FIGURE 2: Effect of light irradiation on 6-azidoriboflavin bound to riboflavin-binding protein. The solution at the end of the titration of Figure 1 was irradiated at $20^{\circ} \mathrm{C}$ with a light intensity of $\sim 5 \times$ $10^{5} \mathrm{erg} \mathrm{cm}^{-2} \mathrm{~s}^{-1}$. Curve with $\lambda_{\max }$ at $432 \mathrm{~nm}$ was obtained before light irradiation; succeeding curves were obtained after $1,2,3,4,6,8,10$, $15,20,25$, and $35 \mathrm{~min}$ of irradiation.

of Choi and McCormick (1980) that isoriboflavin (which has methyl groups at positions 6 and 7 of the isoalloxazine ring system instead of positions 7 and 8 in riboflavin) binds to riboflavin-binding protein with a $K_{\mathrm{d}}$ of $2.7 \times 10^{-8} \mathrm{M}$ vs. 2.1 $\times 10^{-9} \mathrm{M}$ for riboflavin. The study of Choi and McCormick indicates that while the pyrazine ring of the bound flavin is exposed to solvent, the dimethylbenzene ring is buried within the folded protein molecule. This conclusion was also substantiated with our later studies of riboflavin-binding protein complexed with 2-thioriboflavin, 4-thioriboflavin, and 8mercaptoriboflavin (Claiborne et al., 1982; Massey et al., 1984b; Schopfer et al., 1981).

In keeping with the benzene ring portion of the bound flavin being buried, light irradiation of 6-azidoriboflavin-binding protein was found to be a slow process; considerable light exposure was required for destruction of the azido function, as shown in Figure 2. Irradiation results in major spectral changes, which are essentially isosbestic. The final product is also completely nonfluorescent. At intermediate times the presence of remaining 6-azidoriboflavin was detected by de- 


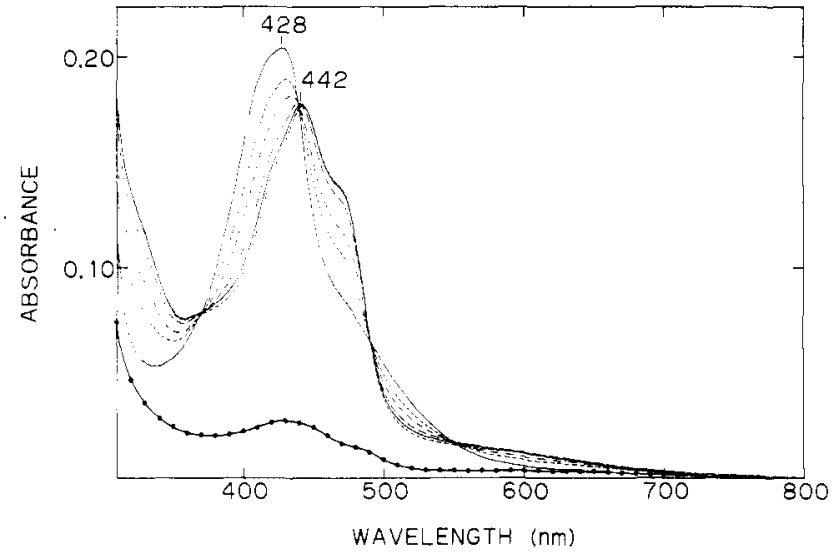

FIGURE 3: Spectral changes on light irradiation of 6- $\mathrm{N}_{3}$-FMN flavodoxin. The holoprotein (curve with $\lambda_{\max } 428 \mathrm{~nm}$ ) was obtained by titration of $6-\mathrm{N}_{3}-\mathrm{FMN}$ with apoflavodoxin, followed by overnight dialysis vs. $0.05 \mathrm{M}$ potassium phosphate buffer, $\mathrm{pH} 7.0$. The succeeding curves to that with $\lambda_{\max }$ of $442 \mathrm{~nm}$ were obtained by irradiation at $20{ }^{\circ} \mathrm{C}$ with a light intensity of $\sim 3 \times 10^{6} \mathrm{erg} \mathrm{cm}^{-2} \mathrm{~s}^{-1}$ for 2 -min periods for a total of $10 \mathrm{~min}$. The sample was then dialyzed for 2 days with shaking vs. $25 \mathrm{~mL}$ of $8 \mathrm{M}$ guanidine hydrochloride, $\mathrm{pH}$ 7 , the volume adjusted to $1 \mathrm{~mL}$ with dialysate, and the spectrum recorded against dialysate in the reference cuvette (๑).

naturation of the protein with $15 \%$ trichloroacetic acid, followed by neutralization and further light irradiation of the supernatant, after the denatured protein was centrifuged off. With the benzene ring of the bound flavin being buried, we had expected that the light-irradiation product of Figure 2 would be a flavin covalently bound to the protein. However, this does not appear to be the case. The light-modified flavin is removed quantitatively from the protein by denaturation with trichloroacetic acid or with $4 \mathrm{M}$ guanidine hydrochloride. The released flavin is highly fluorescent and migrates in all HPLC systems considerably faster than $6-\mathrm{N}_{3}-$ or $6-\mathrm{NH}_{2}$ riboflavin. Its absorption spectrum is also shifted $\sim 10 \mathrm{~nm}$ to shorter wavelengths than the light-irradiation product of Figure 2. The released flavin also binds strongly to fresh apoprotein, with complete quenching of the fluorescence and a return to the spectral characteristics of the light-irradiation product of Figure 2. The nature of the product has not been determined. Conceivably it could be one of the ring-expansion derivatives of the flavin discussed in Scheme II of Ghisla et al. (1986). We hope to test this possibility in future studies. Whatever the nature of the product, it appears clear that the 6-azido function of the bound flavin, even though not exposed to bulk solvent, is located in a hydrophobic pocket of the flavin binding site and not in contact with protein residues with which the photoactivated flavin [presumably the nitrene-cf. Bayley and Knowles (1977) and Chowdhry and Westheimer (1979) for reviews] could react.

Properties of 6-Amino-FMN Flavodoxin and 6-Azido-FMN Flavodoxin. 6-Amino-FMN binds tightly to the apoflavodoxin from Megasphaera elsdenii, with a shift in the $\lambda_{\max }$ from 429 to $434 \mathrm{~nm}$ and a decrease in extinction coefficient from 18000 to $14200 \mathrm{M}^{-1} \mathrm{~cm}^{-1}$. Similarly, $6-\mathrm{N}_{3}-\mathrm{FMN}$ also binds tightly, with a shift in $\lambda_{\max }$ (423 to $428 \mathrm{~nm}$ ) and a decrease in extinction coefficient $\left(19000\right.$ to $16800 \mathrm{M}^{-1} \mathrm{~cm}^{-1}$ ). These changes are similar to those that occur on binding of FMN (Mayhew, 1971). The modified flavins remain with the protein in $0.05 \mathrm{M}$ phosphate ( $\mathrm{pH} 7.0$ ) either when dialyzed overnight or when passed through a Sephadex G-25 column. Figure 3 shows the effect of light irradiation on the 6- $\mathrm{N}_{3}$-FMN protein. Again fairly large fluxes of light are required to bring about the spectral changes. As was the case with riboflavin-binding protein, the light-irradiation product is nonfluorescent while

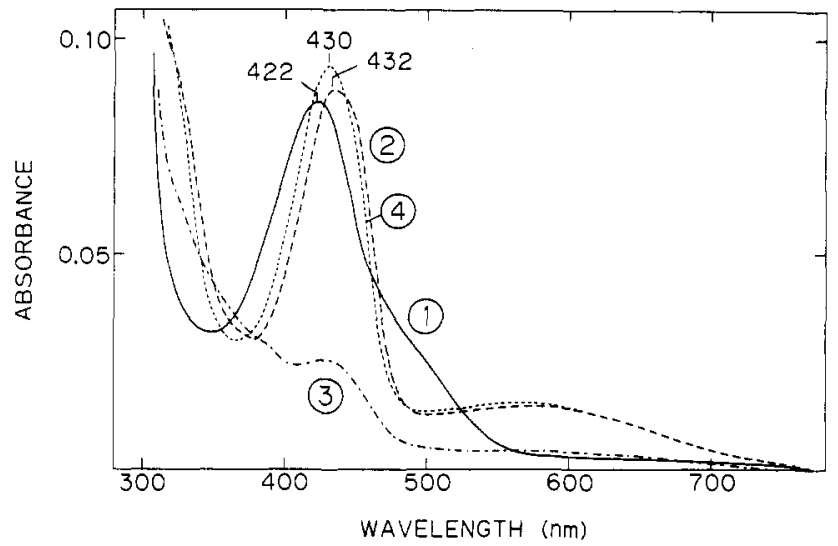

FIGURE 4: Conversion of 6-azido-FMN Old Yellow Enzyme to the 6-amino-FMN enzyme by reduction and catalytic turnover. To a 0.9-mL sample of 6- $\mathrm{N}_{3}$-FMN enzyme that had been dialyzed overnight vs. $0.05 \mathrm{M}$ potassium phosphate buffer, $\mathrm{pH} 7.0$, in an aerobic cuvette at $20^{\circ} \mathrm{C}$ (curve 1) were added, in succession, $3 \mu \mathrm{L}$ of $10^{-3} \mathrm{M} \mathrm{NADP}^{+}$, $10 \mu \mathrm{L}$ of $0.1 \mathrm{M}$ glucose 6-phosphate, and $5 \mu \mathrm{L}$ of a glucose-6-phosphate dehydrogenase solution containing $2 \mathrm{mg}$ of protein $/ \mathrm{mL}$. After an initial substantial drop in absorbance in the $430-\mathrm{nm}$ region, curve 2 was recorded 9 min after addition of the NADPH-generating system. Curve 3 was recorded at $23 \mathrm{~min}$ and curve 4 at $50 \mathrm{~min}$, after mixing again with air.

still protein bound. In this case a small amount of covalent fixation of the flavin to the protein is obtained. Figure 3 shows the residual absorbance remaining after dialysis for 2 days vs. $8 \mathrm{M}$ guanidine hydrochloride at $\mathrm{pH}$ 7.0. The absorbance at $430 \mathrm{~nm}$ of the dialyzed protein in this experiment was $15 \%$ that of the initial 6- $\mathrm{N}_{3}$-FMN flavodoxin. In a similar experiment where the light-irradiated protein was dialyzed vs. $2 \mathrm{M} \mathrm{KBr}$ in $0.1 \mathrm{M}$ acetate at $\mathrm{pH} 3.8$, conditions that resolve FMN from the native protein (Mayhew, 1971), 7\% the initial $A_{430}$ was retained with the protein. The small amount of covalent labeling is consistent with the X-ray crystallographic studies of the related flavodoxin from Clostridium MP (Burnett et al., 1974), which put the flavin molecule close to the surface of the protein, and with the 7,8-dimethyl residues exposed to solvent.

Properties of 6-Amino-FMN and 6-Azido-FMN Bound to the Apoprotein of Old Yellow Enzyme. 6-Amino-FMN is bound reasonably tightly to the apoprotein of Old Yellow Enzyme, with a $K_{d}$ in $0.05 \mathrm{M}$ phosphate, $\mathrm{pH} 7.0$, at $20^{\circ} \mathrm{C}$, of $10^{-7} \mathrm{M}$. This value is, however, considerably larger than that of $10^{-9} \mathrm{M}$ estimated for binding of the native coenzyme FMN (Theorell \& Nygaard, 1954). The spectral properties of the bound 6- $\mathrm{NH}_{2}-\mathrm{FMN}$ are also somewhat unusual, since the $\lambda_{\max }$ of $430 \mathrm{~nm}$ is hardly changed from that of free 6$\mathrm{NH}_{2}$-FMN (429 nm). This should be compared with the 15-20-nm shift to longer wavelengths found with binding of FMN and a series of modified FMN's (Abramovitz \& Massey, 1976; Massey et al., 1984a). The long-wavelength band of $6-\mathrm{NH}_{2}-\mathrm{FMN}(555 \mathrm{~nm})$ does, however, shift in the expected fashion $\left(\lambda_{\max } 580 \mathrm{~nm}\right)$.

The binding of 6- $\mathrm{N}_{3}-\mathrm{FMN}$ is surprisingly much tighter, with a $K_{\mathrm{d}}$ value in $0.05 \mathrm{M}$ phosphate, pH 7.0 , at $20^{\circ} \mathrm{C}$, of $<10^{-8}$ M. As was the case with 6-NH $\mathrm{N}_{2}-\mathrm{FMN}$, there was no significant shift in $\lambda_{\max }$ on binding, the latter remaining at 422 nm (cf. Figure 4). There was, however, a significant decrease in extinction coefficient, to a value of $15400 \mathrm{M}^{-1} \mathrm{~cm}^{-1}$ (calculated from the titration of 6- $\mathrm{N}_{3}-\mathrm{FMN}$ with apoenzyme; results not shown).

In previous studies with 8 -azidoflavins (Fitzpatrick et al., 1985), we showed that $\mathrm{N}_{2}$ was eliminated readily on reduction of the flavin, with formation of the 8-aminoflavin. While the 
Scheme I<smiles>[Y]c1c(C)c(C)cc2c1nc1c(=O)[nH]c(=O)nc-1n2P</smiles><smiles></smiles><smiles>CC(C)C</smiles>

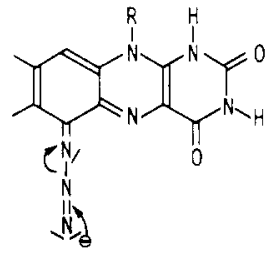

similar conversion of 6- $\mathrm{N}_{3}$-riboflavin to 6- $\mathrm{NH}_{2}$-riboflavin was observed on reduction with dithionite and reoxidation with air, the elimination from the reduced flavin was very much slower than with the corresponding $8-\mathrm{N}_{3}$-flavin, taking hours at $\mathrm{pH}$ $7.0,20^{\circ} \mathrm{C}$, rather than seconds with the 8-substituted flavin. However, a considerable enhancement in the rate of this reaction occurs with 6- $\mathrm{N}_{3}$-FMN bound to apo-Old Yellow Enzyme (Figure 4). Within seconds of the addition of a substoichiometric concentration of $\mathrm{NADP}^{+}$and a NADPHgenerating system to an aerobic solution of $6-\mathrm{N}_{3}-\mathrm{FMN}$ enzyme there was substantial bleaching of the $422-\mathrm{nm}$ absorption, followed within minutes by the appearance of the spectrum shown by curve 2 . As $\mathrm{O}_{2}$ in the cuvette was consumed by catalytic turnover, the enzyme became practically fully reduced, as shown in curve 3. After the solution was mixed several times with air, all of the glucose 6-phosphate of the NADPH-generating system was exhausted, and the spectrum returned to that shown in curve 4 . This is identical with that obtained on binding of $6-\mathrm{NH}_{2}-\mathrm{FMN}$ to the apoenzyme. Further confirmation that the product was $6-\mathrm{NH}_{2}-\mathrm{FMN}$ was obtained by demonstration of the release of the flavin by denaturation with trichloroacetic acid and by the finding of a single peak in HPLC analysis with the same retention time as that of $6-\mathrm{NH}_{2}-\mathrm{FMN}$. These results indicate that the conversion of $6-\mathrm{N}_{3}$-flavin to $6-\mathrm{NH}_{2}$-flavin by reduction occurs in a fashion analogous to that suggested for 8-azidoflavins (Fitzpatrick et al., 1985). These suggested reactions are shown in Scheme I. The spectral characteristics of Figure 4, curve 2 , could be due to an intermediate in the reaction or to binding of NADPH.

The results described in Figure 4 also show that all three flavin forms of the enzyme possess catalytic activity; from the time taken to exhaust the amount of added glucose 6-phosphate, an average NADPH: $\mathrm{O}_{2}$ oxidoreductase activity of $\geqslant 4$ $\mathrm{min}^{-1}$ can be calculated under the suboptimal conditions of Figure 4.

Like native enzyme (Abramovitz \& Massey, 1976) and many flavin-substituted forms of Old Yellow Enzyme (Massey et al., 1984a), both 6- $\mathrm{NH}_{2}-\mathrm{FMN}$ enzyme and $6-\mathrm{N}_{3}-\mathrm{FMN}$ enzyme bind a variety of phenolates. In the case of $6-\mathrm{N}_{3}-\mathrm{FMN}$ Old Yellow Enzyme, phenol, $p$-chlorophenol, and p-nitrophenol give the typical long-wavelength bands that are characteristic of the native enzyme, which are attributable to charge-transfer complexes between the bound phenolate as donor and the oxidized flavin as acceptor (Abramovitz \& Massey, 1976; Massey et al., 1984a; Stewart \& Massey, 1985). With 6$\mathrm{NH}_{2}$-FMN enzyme, while phenolates clearly bind, as judged by changes in the absorption spectrum of the enzyme, the

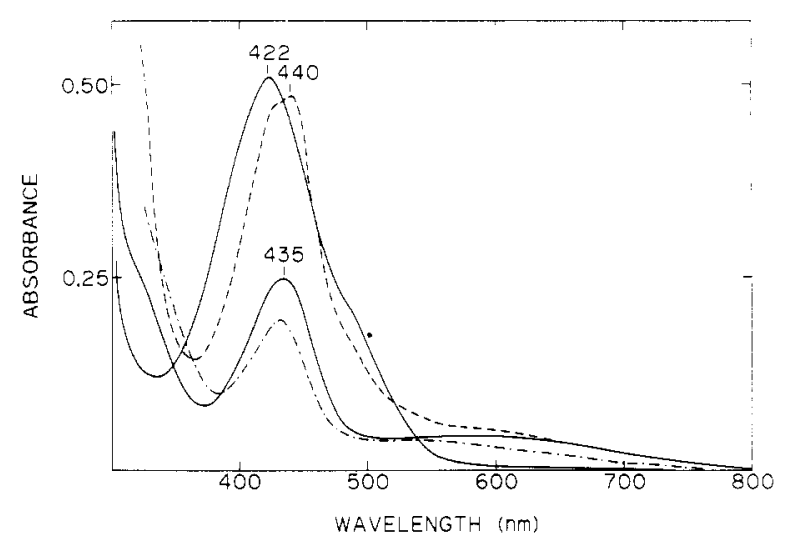

FIGURE 5: Effect of light irradiation on 6-azido-FMN bound to Old Yellow Enzyme. The holoenzyme (upper solid curve with $\lambda_{\max } 422$ $\mathrm{nm}$ ) was prepared by addition of a slight excess of apoprotein to 6- $\mathrm{N}_{3}$-FMN in $0.05 \mathrm{M}$ potassium phosphate buffer, $\mathrm{pH} 7.0$, followed by ultrafiltration via centrifugation through an Amicon Centricon 10 membrane and redissolution of the protein fraction in $1 \mathrm{~mL}$ of buffer. The sample was then irradiated at $20^{\circ} \mathrm{C}$ for $2 \mathrm{~min}$ with light of intensity $\sim 1 \times 10^{6} \mathrm{erg} \mathrm{cm}^{-2} \mathrm{~s}^{-1}$ (dashed curve). The light changes were essentially complete after a 30-s irradiation. The sample was then dialyzed for 2 days vs. $200 \mathrm{~mL}$ of $2 \mathrm{M} \mathrm{KBr}$ in $0.1 \mathrm{M}$ potassium phosphate buffer, $\mathrm{pH} 5.5$, containing $1 \mathrm{~g}$ of activated charcoal in the dialyzing fluid. The charcoal adsorbs released flavin and eliminates the necessity of changing the dialysis fluid in the preparation of apoprotein. The sample was then dialyzed for a further 1 day vs. 200 $\mathrm{mL}$ of $0.05 \mathrm{M}$ potassium phosphate buffer, $\mathrm{pH} 7.0$, to remove $\mathrm{KBr}$ and made up to a volume of $1.0 \mathrm{~mL}$, and the spectrum was recorded (solid curve with $\lambda_{\max } 435 \mathrm{~nm}$ ). To this solution was added glucose 6-phosphate and glucose-6-phosphate dehydrogenase as described in the legend to Figure 4 , followed by aliquots of $10^{-3} \mathrm{M} \mathrm{NADP}^{+}$. The spectrum shown in the lowest curve was obtained rapidly on addition of $12 \mu \mathrm{M} \mathrm{NADP}{ }^{+}$and did not change significantly with time or with further addition of NADP ${ }^{+}$

spectral changes are not necessarily attributable to chargetransfer transitions, as they mainly involve intensification and small shifts of the already existing long-wavelength band of the uncomplexed enzyme. $p$-Nitrophenol binds very tightly $\left(K_{\mathrm{d}}<1 \mu \mathrm{M}\right)$ with both the 6- $\mathrm{N}_{3}-\mathrm{FMN}$ and 6- $\mathrm{NH}_{2}-\mathrm{FMN}$ enzymes. This phenol provides a good test case for phenolate binding, since at $\mathrm{pH} 7$ the added phenol in free solution is largely in the un-ionized form, but binding to the enzyme as the phenolate is accompanied by a large extinction increase, $\sim 18000 \mathrm{M}^{-1} \mathrm{~cm}^{-1}$ (Massey et al., 1984a).

Figure 5 shows the effect of light irradiation on 6- $\mathrm{N}_{3}$-FMN Old Yellow Enzyme. In distinction to the slowly produced changes already described for riboflavin-binding protein and flavodoxin, the photoreaction with Old Yellow Enzyme is very facile, with the changes shown in Figure 5 being complete within the shortest period of irradiation given $(30 \mathrm{~s})$. Now, also, photoirradiation results in approximately $50 \%$ covalent fixation of the flavin to the protein. This value was found consistently either by denaturation of the protein with trichloroacetic acid or $8 \mathrm{M}$ guanidine hydrochloride or by dialysis at $\mathrm{pH} 5.2$ vs. $2 \mathrm{M} \mathrm{KBr}$, conditions known to resolve FMN from the native enzyme without denaturation (Abramovitz \& Massey, 1976). The resulting covalently bound flavin is no longer able to bind phenols, as judged by lack of spectral changes even on the addition of high concentrations of phenol, $p$-chlorophenol, or $p$-nitrophenol. It would appear likely, therefore, that light irradiation results in reaction of the photogenerated flavin-6-nitrene with the active-site base responsible for binding of phenolates to the native enzyme (Massey \& Schopfer, 1986). The binding of NADPH to the light-irradiated enzyme is not abolished, however. Figure 5 shows that addition of an approximately stoichiometric concentration of NADP ${ }^{+}$and a NADPH-regenerating system 
Scheme II

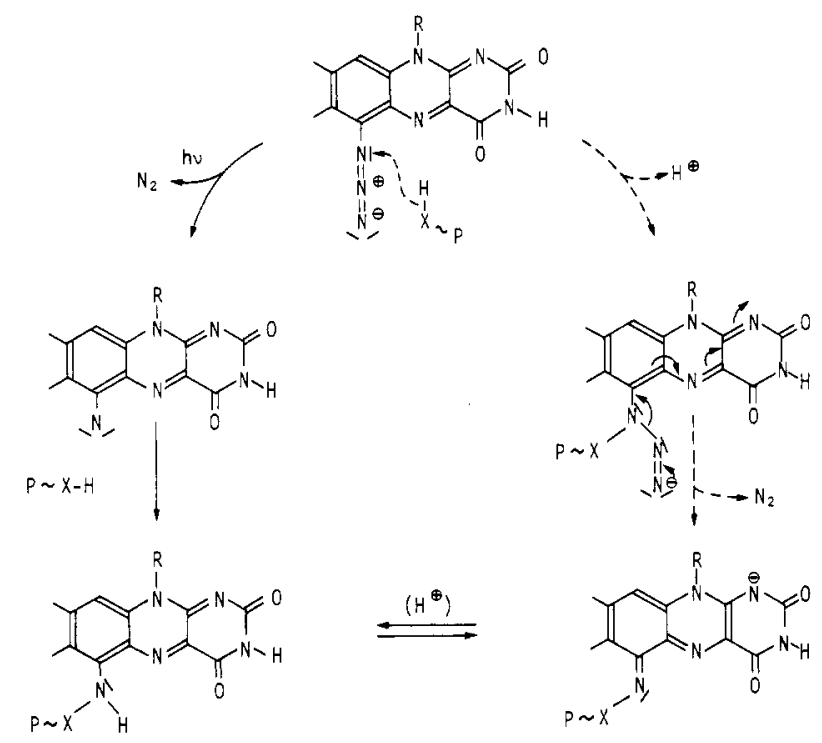

results in a perturbation of the spectrum of the covalently bound flavin but not in its reduction. Hence it may be concluded that the covalent fixation of the flavin to the enzyme does not prevent tight binding of NADPH but that reduction is prevented. This may result from a distortion of the active site so that NADPH is not able to position itself so as to permit hydride transfer to the flavin. Alternatively, the phenolate binding site may itself play an important role in reduction of the flavin. The stability of the flavin-protein linkage should be compared with the labile linkage found with D-amino acid oxidase (cf. next section) and presumably implies reaction of the flavin with an amino or guanidino function, which might be expected to be stable.

The formation of a covalent linkage between flavin and protein as a result of light irradiation may, in principle, result from either of the two pathways shown in Scheme II. The left-hand pathway is that to be expected from the usual photochemistry of aryl azides, involving $\mathrm{N}_{2}$ elimination in the photochemical event, followed by attack of the resulting nitrene on any available protein- $\mathrm{X}-\mathrm{H}$ residue to give the insertion reaction shown. However, such a reaction would be expected to be quite nonspecific, with the nitrene reacting equally well with any available $\mathrm{H}_{2} \mathrm{O}$ molecules. The high yield of covalent linkage found with Old Yellow Enzyme (>50\%) and with D-amino acid oxidase ( $\geqslant 90 \%$; cf. next section) suggests the possibility of an alternative pathway, as shown on the righthand side of Scheme II. We observed that nucleophiles such as sulfite and thiols brought about the conversion of 8-azidoflavins to 8-aminoflavins (Fitzpatrick et al., 1985); similar reactions have been found with 6-azidoflavins. Thus, at $\mathrm{pH}$ $8.5,20^{\circ} \mathrm{C}$, the addition of $10 \mathrm{mM}$ dithiothreitol to 6-azidoFMN results in the quantitative conversion to $6-\mathrm{NH}_{2}-\mathrm{FAD}$ with a $t_{1 / 2}$ of 20 min (results not shown). Indeed, such a dark reaction occurs with $6-\mathrm{N}_{3}-\mathrm{FMN}$ lactate oxidase at $\mathrm{pH} 7$, where a protein thiolate residue appears to bring about conversion to the 6- $\mathrm{NH}_{2}-\mathrm{FMN}$ enzyme (cf. later section). With the known ability of flavins and flavoproteins to undergo photochemical reactions, it is thus conceivable that a dark reaction such as that shown in Scheme II, right-hand side, would be very much accelerated by light irradiation, thus leading to a high yield of specific covalent labeling. The stability of the covalent linkage would of course depend on the nature of $X$; if $\mathrm{X}$ were $\mathrm{N}$ or $\mathrm{C}$, a stable linkage would be expected. On the other hand, if $\mathrm{X}-\mathrm{H}$ were $\mathrm{S}-\mathrm{H}$ or an acidic $\mathrm{O}-\mathrm{H}$, the bond might be sufficiently weak to be stable against hydrolysis only

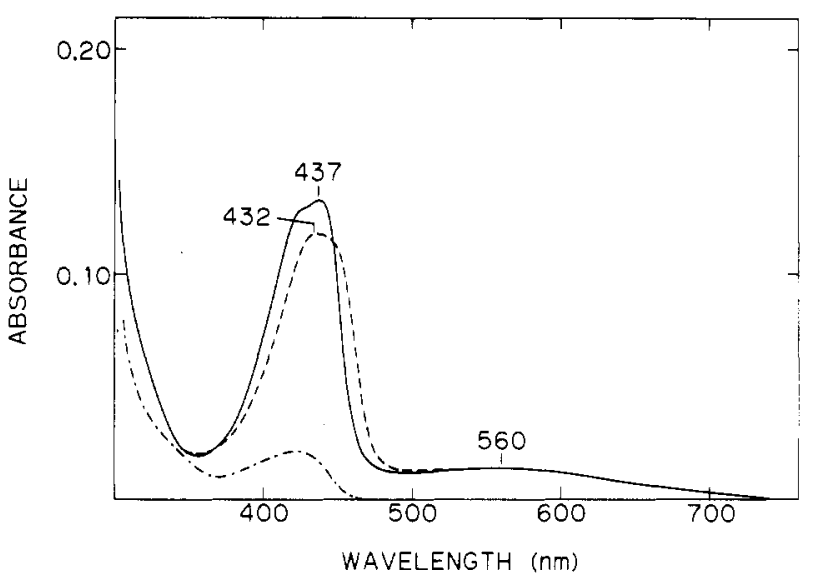

FIGURE 6: Effect of substrate and benzoate on the spectrum of 6- $\mathrm{NH}_{2}$-FAD D-amino acid oxidase. The 6- $\mathrm{NH}_{2}$-FAD enzyme, in 0.02 $\mathrm{M}$ pyrophosphate buffer, $\mathrm{pH} 8.5,20^{\circ} \mathrm{C}$ (solid curve) was treated either with $10^{-4} \mathrm{M}$ benzoate (dashed curve) or with $10 \mathrm{mM}$ D-alanine (dot-dashed curve). For more details, see text.

when protected by the native protein structure.

Properties of 6-Amino-FAD and 6-Azido-FAD D-Amino Acid Oxidase. As is the case with native enzyme, which binds FAD with only medium affinity, $K_{\mathrm{d}} \sim 10^{-7} \mathrm{M}$ at $\mathrm{pH} 8.5,20$ ${ }^{\circ} \mathrm{C}$ (Massey et al., 1966; Okuda et al., 1979), the binding of 6- $\mathrm{NH}_{2}-\mathrm{FAD}$ and of 6-N $-\mathrm{FAD}$ to apo-D-amino acid oxidase is weaker than with the other proteins so far discussed. On titration of 6- $\mathrm{N}_{3}$-FAD with the apoprotein there is a shift in the $\lambda_{\max }$ from 428 to $421 \mathrm{~nm}$, with essentially no change in extinction coefficient $\left(17500 \mathrm{M}^{-1} \mathrm{~cm}^{-1}\right.$; Ghisla et al., 1986). On gel filtration through Sephadex G-25, in 0.02 M pyrophosphate, $\mathrm{pH} 8.5,22^{\circ} \mathrm{C}, 71 \%$ of the flavin remained associated with the protein. Similar experiments with $6-\mathrm{NH}_{2}-\mathrm{FAD}$ showed only slight shifts in the spectrum on binding to the apoprotein (565-nm band shifted to $555 \mathrm{~nm}$ and $432-\mathrm{nm}$ band shifted to $437 \mathrm{~nm}$ ) and little change in the extinction coefficient. The 6-NH $-\mathrm{NH}_{2}-\mathrm{FD}$ enzyme is readily reduced by D-alanine, as shown in Figure 6. An intermediate with increased absorption in the 470-600-nm region and a $\lambda_{\max }$ of $\sim 530 \mathrm{~nm}$ is observed and is sufficiently stable to be recorded under aerobic turnover conditions. At $\mathrm{pH} 8.5,20^{\circ} \mathrm{C}$, it decays to the spectrum shown in Figure 6 with a $t_{1 / 2}$ of less than 3 min. By analogy with native enzyme, this probably represents a reduced enzyme-imino acid charge-transfer complex (Yagi et al., 1967; Massey \& Ghisla, 1974). The 6- $\mathrm{NH}_{2}-\mathrm{FAD}$ enzyme, like native enzyme (Yagi \& Ozawa, 1962; Quay \& Massey, 1977), also binds benzoate tightly, with a $K_{\mathrm{d}}$ value of $<10^{-5} \mathrm{M}$. The spectral changes induced by benzoate are, however, somewhat unusual, as shown in Figure 6. In the case of native enzyme, the main visible absorption band is shifted by $\sim 10 \mathrm{~nm}$ to longer wavelength, while in the present case the $\lambda_{\max }$ is actually lowered to $432 \mathrm{~nm}$ and the spectral resolution usually observed is quite absent. By contrast, benzoate binding to $6-\mathrm{N}_{3}$-FAD enzyme $\left(K_{d}<10^{-5} \mathrm{M}\right)$ gives a wellresolved spectrum, with a double maximum, 432 and $488 \mathrm{~nm}$ (results not shown).

Like 6- $\mathrm{N}_{3}$-FMN Old Yellow Enzyme (cf. previous section), 6- $\mathrm{N}_{3}$-FAD D-amino acid oxidase is rapidly converted to the 6- $\mathrm{NH}_{2}$-FAD enzyme by substrate. When $4.4 \mu \mathrm{M} 6-\mathrm{N}_{3}$-FAD enzyme was reacted aerobically with $55 \mu \mathrm{M}$ D-alanine, by the time the first spectrum could be recorded, the long-wavelength band typical of the 6-NH $-\mathrm{NH}_{2}$-FAD enzyme was present, and after 5 min a stable spectrum was obtained, which is identical with that obtained on titration of 6- $\mathrm{NH}_{2}-\mathrm{FAD}$ with the apoprotein. The identity of the modified flavin as $6-\mathrm{NH}_{2}-\mathrm{FAD}$ was confirmed by release with trichloroacetic acid and HPLC analysis. 


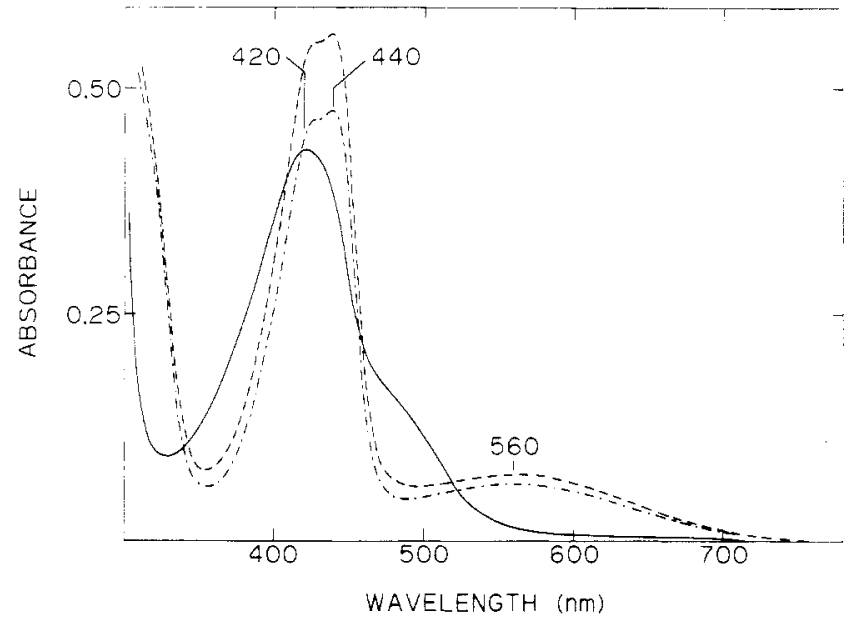

FIGURE 7: Effect of light irradiation on 6- $\mathrm{N}_{3}-\mathrm{FAD}$ D-amino acid oxidase. The 6- $\mathrm{N}_{3}-\mathrm{FAD}$ enzyme was obtained by incubation of approximately equimolar flavin and apoprotein for $40 \mathrm{~min}$ at $20^{\circ} \mathrm{C}$, followed by removal of a small amount of free flavin by centrifuging for $70 \mathrm{~min}$ at $5000 \mathrm{~g}$ through a Centricon $10 \mathrm{membrane}$ and redissolution of the protein in $1 \mathrm{~mL}$ of $0.02 \mathrm{M}$ pyrophosphate, $\mathrm{pH} 8.5$ (solid curve). The spectrum after $30 \mathrm{~s}$ of light irradiation at an intensity of $\sim 1 \times 10^{6} \mathrm{erg} \mathrm{cm}^{-2} \mathrm{~s}^{-1}$ is shown by the dashed curve. Solid $\mathrm{KBr}$ was then added to $2 \mathrm{M}$, and the solution was centrifuged for $70 \mathrm{~min}$ through a Centricon 10 ultrafiltration membrane. The protein was redissolved in $1 \mathrm{~mL}$ of $2 \mathrm{M} \mathrm{KBr} / 0.02 \mathrm{M}$ pyrophosphate, $\mathrm{pH} 8.5$, and centrifuged again, before being redissolved in $1 \mathrm{~mL}$ of $0.02 \mathrm{M}$ pyrophosphate, $\mathrm{pH} 8.5$ (dot-dashed curve).

The turnover-modified enzyme also behaved identicalfy with respect to benzoate binding and reduction with excess $\mathrm{D}$-alanine as already described for the 6- $\mathrm{NH}_{2}-\mathrm{FAD}$ enzyme.

The effect of light irradiation on the 6- $\mathrm{N}_{3}$-FAD enzyme is shown in Figure 7. The photoreaction is very rapid, being complete with the shortest period of irradiation employed ( 30 s). While the spectral characteristics of the light-irradiated enzyme are generally similar to those of the 6- $\mathrm{NH}_{2}$ - FAD enzyme, there are several important differences. First, there is a substantial increase in absorption to a new species with a $\lambda_{\max }$ of $440 \mathrm{~nm}$ and an extinction coefficient of $\sim 23000 \mathrm{M}^{-1}$ $\mathrm{cm}^{-1}$. This should be compared with the $6-\mathrm{NH}_{2}-\mathrm{FAD}$ enzyme, with a $\lambda_{\max }$ of $437 \mathrm{~nm}$ and an extinction coefficient of 20200 $\mathrm{M}^{-1} \mathrm{~cm}^{-1}$. Second, while the $6-\mathrm{NH}_{2}-\mathrm{FAD}$ enzyme is readily reduced by excess $D$-alanine even without the removal of dissolved $\mathrm{O}_{2}$ (i.e., the $\mathrm{O}_{2}$ is removed by catalytic turnover), the light-irradiation product is not reduced by $D$-alanine over a 20 -h period even under anaerobic conditions. Third, while benzoate induces the distinct spectral changes with $6-\mathrm{NH}_{2-}$ FAD enzyme shown in Figure 6, addition of benzoate is without effect on the spectrum of the light-irradiation product. Fourth, at least $85 \%$ of the flavin remains associated with the protein when treated with $2 \mathrm{M} \mathrm{KBr}$ and subjected to ultrafiltration twice through an Amicon Centricon 10 membrane. Under the same conditions $>95 \%$ of the FAD of the native enzyme or the $6-\mathrm{NH}_{2}-\mathrm{FAD}$ of the $6-\mathrm{NH}_{2}-\mathrm{FAD}$ enzyme is removed into the ultrafiltrate.

The properties listed above argue strongly for an almost quantitative covalent labeling by the flavin-excited state of a catalytically important protein residue (cf. Scheme II). This could be either the base responsible for benzoate binding (and presumably also substrate binding; Yagi \& Ozawa, 1962; Quay \& Massey, 1977) or the base presumed to be responsible for proton abstraction from the substrate $\alpha$-carbon, a primary step in the catalytic mechanism (Yagi et al., 1970; Walsh et al., 1971). Either of these possibilities would account for the observed properties of the covalent product. Attachment of the flavin to the protein through another reactive group in the

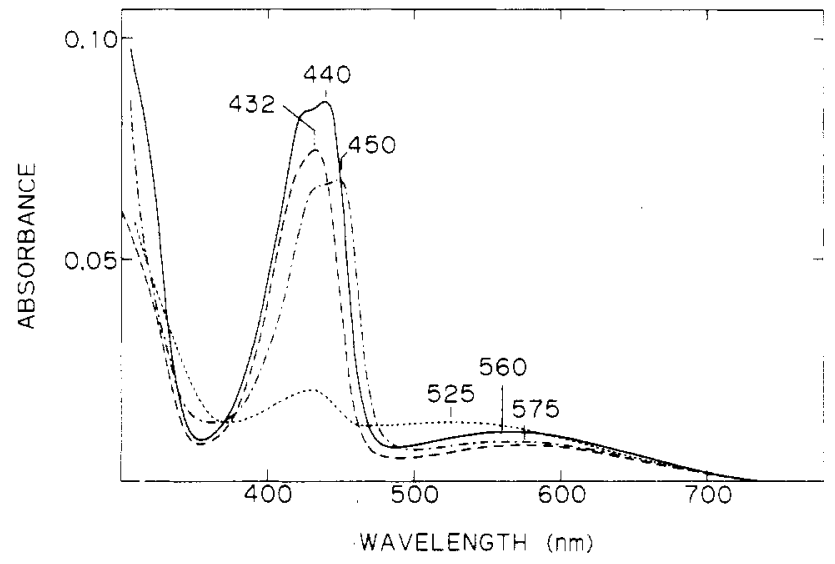

FIGURE 8: Effect of rebinding to fresh apo-D-amino acid oxidase the flavin obtained from denaturation of the light-irradiated $6-\mathrm{N}_{3}-\mathrm{FAD}$ enzyme. (-) Covalently linked flavin obtained by light irradiation of 6-N $\mathrm{N}_{3}-\mathrm{FAD}$ enzyme and $\mathrm{KBr}$ ultrafiltration, as in Figure 8. (--) Spectrum of the flavin released by addition of 10 volumes of methanol at room temperature, filtered for removal of the protein, evaporated to dryness under reduced pressure, and redissolved in the original volume of $\mathrm{H}_{2} \mathrm{O}$. (-.-) Spectrum obtained by addition of fresh apoprotein and $10^{-4} \mathrm{M}$ benzoate. (---) Same treatment as the previous, except that $10 \mathrm{mM} \mathrm{D-alanine} \mathrm{was} \mathrm{added} \mathrm{aerobically,} \mathrm{instead} \mathrm{of}$ benzoate. It should be noted that neither substrate nor benzoate had any effect on the spectrum of the light-irradiation product from 6- $\mathrm{N}_{3}-\mathrm{FAD}$ enzyme ( - ) before denaturation.

active site is not ruled out, since such a linkage could interfere either with ligand binding or with proton abstraction through distortion of the active site. Unfortunately, it will not prove easy to determine which of these possibilities applies, since the covalent linkage formed is quite unstable to denaturation of the protein. Thus, any of the common methods of protein denaturation, such as trichloroacetic acid, sodium dodecyl sulfate, $8 \mathrm{M}$ guanidine hydrochloride, heat, or methanol treatment, release the flavin from the protein.

Given this instability, we considered it essential to obtain further evidence for the proposed flavin-protein covalent linkage. If the proposed linkage was unstable to denaturation of the protein, then presumably the flavin released would have different properties from that covalently linked to the protein. The flavin released by precipitation of the protein with methanol was found to have HPLC mobilities indistinguishable from those of $6-\mathrm{NH}_{2}-\mathrm{FAD}$. However, it was simple to show that the product was not $6-\mathrm{NH}_{2}-\mathrm{FAD}$, since on rebinding to fresh apo-D-amino acid oxidase, the resulting holoprotein had quite different properties from either $6-\mathrm{NH}_{2}-\mathrm{FAD}$ enzyme or the light-irradiation product from $6 \cdot \mathrm{N}_{3}$-FAD enzyme. These are illustrated by comparison of Figures 8 and 6 . In Figure 8 it is shown that the flavin released by methanol denaturation has a $\lambda_{\max }$ of $432 \mathrm{~nm}$, identical with that of $6-\mathrm{NH}_{2}-\mathrm{FAD}$. On rebinding to fresh apoenzyme, the $\lambda_{\max }$ is located at $435 \mathrm{~nm}$, not significantly different from that of the 6- $\mathrm{NH}_{2}-\mathrm{FAD}$ enzyme, $437 \mathrm{~nm}$ (results not shown). The properties of the new holoenzyme are, however, quite different from either 6 $\mathrm{NH}_{2}$-FAD enzyme or the light-irradiation product from 6$\mathrm{N}_{3}$-FAD enzyme. On the addition of D-alanine, there is a rapid change in spectrum with considerable bleaching of the $435-\mathrm{nm}$ band and a shift in the long-wavelength absorption to a maximum at $525 \mathrm{~nm}$. This behavior is similar to that found with $6-\mathrm{NH}_{2}-\mathrm{FAD}$ enzyme, but whereas the longwavelength absorption with that enzyme subsequently disappears with a $t_{1 / 2}$ of $\sim 3 \mathrm{~min}$, that of the new holoenzyme has a $t_{1 / 2}$ for decay on the order of hours. The second very different behavior is that shown on addition of benzoate, which shifts the $\lambda_{\max }$ to $450 \mathrm{~nm}$ (Figure 8 ). This should be compared 
with the value of $432 \mathrm{~nm}$ for the 6-NH -FAD enzyme and with the lack of any spectral change for the light-irradiation product of the 6- $\mathrm{N}_{3}$-FAD enzyme. Thus it is clear that the light-irradiation product is indeed a covalent linkage between the flavin and the protein, which on denaturation of the protein is hydrolyzed to a flavin with properties similar to, but not identical with, those of 6-NH$-\mathrm{NH}_{2}-\mathrm{FAD}$. A likely candidate for the released flavin is 6-NHOH-FAD, which might have spectral and HPLC migration properties similar to those of 6- $\mathrm{NH}_{2}-\mathrm{FAD}$. Unfortunately, we have not yet succeeded in synthesis of 6-NHOH-flavins and so cannot test this hypothesis directly. The lability of the covalent linkage suggests that the protein residue involved might be a thiol, a carboxyl, or possibly an arginine (cf. Scheme II).

When the light irradiation of the $6-\mathrm{N}_{3}-\mathrm{FAD}$ enzyme is carried out in the presence of benzoate, the same final product is obtained as in the absence of benzoate but considerably more light exposure is required. For example, while the light-irradiation changes shown in Figure 7 were complete within the shortest time of irradiation employed ( $30 \mathrm{~s}$ ), it took over $4 \mathrm{~min}$ of irradiation for the same changes to occur in the presence of $3.5 \times 10^{-4} \mathrm{M}$ benzoate. On ultrafiltration with $2 \mathrm{M} \mathrm{KBr}$, the modified flavin remains associated with the protein and has the same spectral properties and lack of reactivity with either substrate or benzoate as already described for the light-irradiation product obtained in the absence of benzoate. These results indicate that benzoate binding in fact prevents the light reaction from occurring and that covalent labeling occurs only with the free enzyme, which is in dynamic equilibrium with its benzoate complex.

Properties of 6-Amino-FMN and 6-Azido-FMN Lactate Oxidase. Both 6- $\mathrm{NH}_{2}-\mathrm{FMN}$ and $6-\mathrm{N}_{3}-\mathrm{FMN}$ bind quite tightly to the apoprotein of the L-lactate oxidase of $\mathrm{Myco}$ bacterium smegmatis. While we have not determined the $K_{\mathrm{d}}$ values or extinction coefficients, because of the instability of the apoprotein, most of the flavin stays associated with the protein on ultrafiltration or dialysis. Spectra of the holoenzymes isolated in this manner at pH 5.6 are shown in Figure 9 , curves 1 (6- $\mathrm{N}_{3}-\mathrm{FMN}$ enzyme) and $4\left(6-\mathrm{NH}_{2}-\mathrm{FMN}\right.$ enzyme). It is necessary to prepare the 6- $\mathrm{N}_{3}$-FMN enzyme at low $\mathrm{pH}$, since at $\mathrm{pH} 7$ it converts slowly and spontaneously to the 6- $\mathrm{NH}_{2}-\mathrm{FMN}$ form. This is probably due to reaction with an active-site thiolate residue, first detected in studies with the enzyme substituted with 4-thio-FMN (Massey et al., 1984 ) and substantiated with enzyme in which the native flavin was replaced by 6-thiocyanato-FMN (Massey et al., 1986). The 6- $\mathrm{N}_{3}$-FMN enzyme is stable for at least 3 days at $\mathrm{pH}$ 5.6, and all of the studies reported here were carried out at this $\mathrm{pH}$ value.

The effect of light irradiation on the 6- $\mathrm{N}_{3}-\mathrm{FMN}$ enzyme appears to be different from that on the other proteins studied, in that most of the spectral change that occurs does so in a subsequent slow dark reaction. Figure 9, curve 2, shows the effect of $2 \mathrm{~min}$ of light irradiation followed by overnight dark incubation $\left(t_{1 / 2}\right.$ of dark reaction, $\sim 30 \mathrm{~min}$ at $\left.20^{\circ} \mathrm{C}\right)$. No further changes occur on further irradiation and subsequent dark incubation. The decreases in absorbance in the 430 - and $500-\mathrm{nm}$ regions are associated mainly with the light reaction, while the increase in absorbance in the $600-\mathrm{nm}$ region occurs mainly in the dark. In view of many similar properties between D-amino acid oxidase and L-lactate oxidase, including reaction mechanism [see Massey and Ghisla (1983) for a review], we had expected that covalent labeling of the flavin with a catalytically important residue of the protein would have occurred. However, the light-irradiation-dark-decay product from the

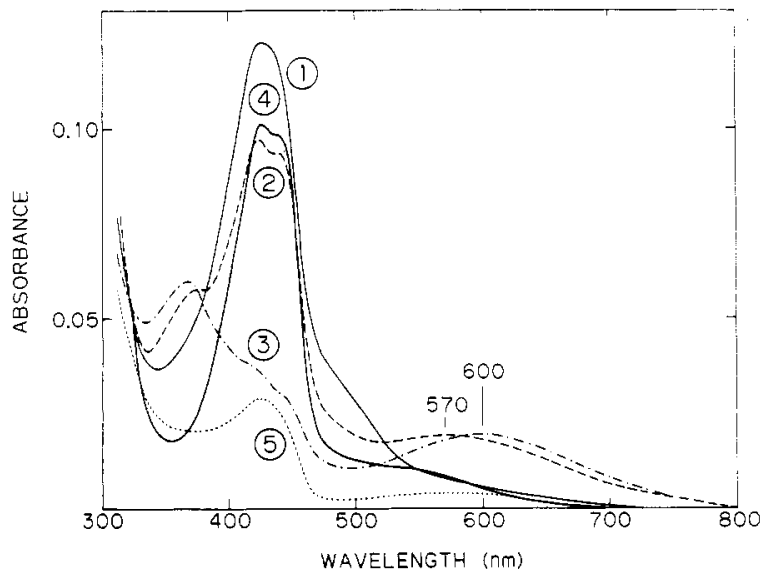

FIGURE 9: Effect of light irradiation on 6- $\mathrm{N}_{3}$-FMN lactaie oxidase, and comparison of properties with those of $6-\mathrm{NH}_{2}-\mathrm{FMN}$ enzyme. Curve 1 , spectrum for $6-\mathrm{N}_{3}$-FMN enzyme obtained by mixing freshly prepared apoenzyme with an approximately 1.5 -fold excess of 6$\mathrm{N}_{3}$-FMN in $0.1 \mathrm{M}$ acetate buffer, $\mathrm{pH} 5.6$, followed by incubation at room temperature for $15 \mathrm{~min}$ and gel filtration with Sephadex G-25 equilibrated with $0.1 \mathrm{M}$ acetate, $\mathrm{pH}$ 5.6. Curve 2, spectrum obtained after 2 min of light irradiation at an intensity of $\sim 1 \times 10^{6} \mathrm{erg} \mathrm{cm}^{-2}$ $\mathrm{sec}^{-1}$ and $16 \mathrm{~h}$ in the dark. Curve 3 , spectrum obtained $10 \mathrm{~min}$ after the aerobic addition of $10 \mathrm{mM}$ L-lactate. The reaction was followed at $430 \mathrm{~nm}$; during the first $3 \mathrm{~min}$ there was very little decrease in $A_{430}$, but then, as the dissolved $\mathrm{O}_{2}$ in the cuvette became exhausted through turnover, the absorbance fell sharply, to the spectrum shown. Curve 4, spectrum of 6- $\mathrm{NH}_{2}$-FMN lactate oxidase, obtained as described for curve 1, except that the enzyme was dialyzed instead of being freed of excess flavin by gel filtration. Curve 5, spectrum obtained $10 \mathrm{~min}$ after aerobic addition of $10 \mathrm{mM} \mathrm{L}$-lactate. As with the experiment of curve 3 , approximately 3 min elapsed before the dissolved $\mathrm{O}_{2}$ was consumed and the $A_{430}$ reading dropped sharply toward that of the reduced enzyme.

6- $\mathrm{N}_{3}-\mathrm{FMN}$ enzyme is readily reduced by L-lactate, as shown in Figure 9, curve 3. The spectral changes are quite unusual in that the long-wavelength band is not bleached and is shifted by $30 \mathrm{~nm}$ to $600 \mathrm{~nm}$. This behavior should be compared with that shown by the $6-\mathrm{NH}_{2}$-enzyme, where both the $420-\mathrm{nm}$ and the long-wavelength absorbances are bleached on reduction.

So far we have not been able to determine whether any covalent linkage between the flavin and protein occurs as a result of the light irradiation. However, it would appear likely that a covalent linkage to the protein is in fact formed in the light reaction and that this subsequently hydrolyzes to give the spectral changes associated with the dark reaction. Thus, in spite of the apparently large differences between the light reactions with $6-\mathrm{N}_{3}-\mathrm{FMN}$ lactate oxidase and $6-\mathrm{N}_{3}-\mathrm{FAD}$ D-amino acid oxidase, the two proteins probably react in a parallel manner, with the difference that the linkage formed with lactate oxidase is even more unstable than that with D-amino acid oxidase, hydrolyzing slowly even when protein bound. This implies that the protein- $X$ residue (cf. Scheme II) is possibly a thiol or carboxyl residue, which would be expected to be unstable. In fact, there is evidence for a thiol residue located near the flavin 6-position (Massey et al., 1986). On hydrolysis such a linkage would form the 6- $\mathrm{NHOH}$-flavin and regenerate the original protein residue. The spectral properties of 6-NHOH-flavins would be expected to be somewhat similar to those of $6-\mathrm{NH}_{2}$-flavins, consistent with the results shown in Figure 9. We plan in future studies to explore these possibilities further. In the meantime it is clear that, despite many similarities in properties between $D$-amino acid oxidase and L-lactate oxidase, there are also quite significant differences in the active site around the flavin 6position, and in particular it appears that the function reacting with the azide is different. 


\section{CONCLUSIONS}

Although we have so far studied only a small number of flavoproteins in which the native flavin has been substituted by the appropriate $6-\mathrm{N}_{3}$-flavin, the results of light irradiation suggest that this may be a very useful way of probing the active-site region of flavoproteins close to the catalytically important $\mathrm{N}(5)$ center. The results should be contrasted with those obtained with $8-\mathrm{N}_{3}$-flavins (Fitzpatrick et al., 1985), where in most cases only a small extent of covalent labeling to individual flavoproteins was found, consistent with solvent accessibility to the flavin 8-position. The results of light irradiation of $6-\mathrm{N}_{3}-\mathrm{FMN}$ flavodoxin, giving very little covalent labeling, are also consistent with solvent accessibility to the flavin 6-position, where reaction of the photogenerated nitrene with water seems to be the predominant event. In contrast, the extensive covalent labeling of the protein obtained on light irradiation of 6-N - FMN Old Yellow Enzyme, 6- $\mathrm{N}_{3}$-FAD D-amino acid oxidase, and probably also 6-N $-\mathrm{FMN}$ lactate oxidase argues for limited solvent access to the flavin 6-position in these proteins, in general agreement with the results obtained with other chemically reactive 6-substituted flavins (Massey et al., 1986). The high degree of covalent labeling found with 6- $\mathrm{N}_{3}$-flavin-substituted Old Yellow Enzyme and with D-amino acid oxidase is in fact unusual for photoreactions of protein-bound aryl azides and suggests the possibility of specific nucleophilic attack of protein residues on the azide linkage, which might be greatly accelerated photochemically (cf. Scheme II).

\section{REFERENCES}

Abramovitz, A., \& Massey, V. (1976) J. Biol. Chem. 251, 5327-5336.

Bayley, H., \& Knowles, J. R. (1977) Methods Enzymol. 46, 69-114.

Beinert, W.-D., Rüterjans, H., \& Müller, F. (1985) Eur. J. Biochem. 152, 573-579.

Biemann, M., Claiborne, A., Ghisla, S., Massey, V., \& Hemmerich, P. (1983) J. Biol. Chem. 258, 5440-5448.

Burnett, R. M., Darling, G. D., Kendall, D. S., LeQuesne, M., Mayhew, S. G., Smith, W. W., \& Ludwig, M. L. (1974) J. Biol. Chem. 249, 4383-4392.

Choi, J.-D., \& McCormick, D. B. (1980) Arch. Biochem. Biophys. 204, 41-51.

Chowdhry, V., \& Westheimer, F. H. (1979) Annu. Rev. Biochem. 48, 293-325.

Claiborne, A., Massey, V., Fitzpatrick, P. F., \& Schopfer, L. M. (1982) J. Biol. Chem. 257, 174-182.

Edmondson, D., Barman, B., \& Tollin, G. (1972) Biochemistry 11, 1133-1138.

Fisher, J., Spencer, R., \& Walsh, C. (1976) Biochemistry 15, 1054-1064.

Fitzpatrick, P. F., Ghisla, S., \& Massey, V. (1985) J. Biol. Chem. 260, 8483-8491.

Ghisla, S., \& Mayhew, S. G. (1976) Eur. J. Biochem. 63, 373-390.

Ghisla, S., Massey, V., \& Yagi, K. (1986) Biochemistry 25, 3282-3289.

Hille, R., Fee, J. A., \& Massey, V. (1981) J. Biol. Chem. 256, 8933-8940.

Jorns, M., \& Hersh, L. (1975) J. Biol. Chem. 250, 3620-3628. Karplus, P. A., \& Herriott, J. R. (1982) in Flavins and Fla- voproteins (Massey, V., \& Williams, C. H., Eds.) pp 28-31, Elsevier, New York.

Kasai, S., Sugimoto, K., Miura, R., Yamano, T., \& Matsui, K. (1983) J. Biochem. (Tokyo) 93, 397-402.

Kitagawa, T., Nishina, Y., Kyogoku, Y., Yamano, T., Ohishi, N., Takai-Suzuki, A., \& Yagi, K. (1979) Biochemistry 18, 1804-1808.

Koberstein, R. (1976) Eur. J. Biochem. 67, 223-229.

Light, D. R., \& Walsh, C. (1980) J. Biol. Chem. 255, 4264-4277.

Massey, V., \& Ghisla, S. (1974) Ann. N.Y. Acad. Sci. 227, 446-465.

Massey, V., \& Hemmerich, P. (1980) Biochem. Soc. Trans. 8, 246-257.

Massey, V., \& Ghisla, S. (1983) 34th Mosbach Colloquium (Sund, H., \& Ullrich, V., Eds.) pp 114-139, SpringerVerlag, Berlin.

Massey, V., \& Schopfer, L. M. (1986) J. Biol. Chem. 261, 1215-1222.

Massey, V., Curti, B., \& Ganther, H. (1966) J. Biol. Chem. 241, 2347-2357.

Massey, V., Ghisla, S., \& Moore, E. G. (1979) J. Biol. Chem. 254, 9640-9650.

Massey, V., Schopfer, L. M., \& Dunham, W. R. (1984a) in Flavins and Flavoproteins (Bray, R. C., Engel, P. C., \& Mayhew, S. G., Eds.) pp 191-210, de Gruyter, Berlin.

Massey, V., Claiborne, A., Biemann, M., \& Ghisla, S. (1984b) J. Biol. Chem. 259, 9667-9678.

Massey, V., Ghisla, S., \& Yagi, K. (1986) Biochemistry (following paper in this issue).

Mayhew, S. G. (1971) Biochim. Biophys. Acta 235, 289-302.

Mayhew, S. G., Whitfield, C. D., Ghisla, S., \& Jorns, M. (1974) Eur. J. Biochem. 44, 579-591.

Moore, E. G., Ghisla, S., \& Massey, V. (1979) J. Biol. Chem. 254, 8173-8178.

Nishimoto, K., Watanabe, Y., \& Yagi, K. (1978) Biochim. Biophys. Acta 526, 34-41.

Okuda, J., Nagamine, J., \& Yagi, K. (1979) Biochim. Biophys. Acta 566, 245-252.

Quay, S., \& Massey, V. (1977) Biochemistry 16, 3348-3354.

Schopfer, L. M., Massey, V., \& Claiborne, A. (1981) J. Biol. Chem. 256, 7329-7337.

Schulz, G. E., Schirmer, R. H., \& Pai, E. (1982) J. Mol. Biol. 160, 287-308.

Stewart, R. C., \& Massey, V. (1985) J. Biol. Chem. 260, 13639-13647.

Sullivan, P. A., Choong, Y. S., Schreurs, W. G., Cutfield, J. F., \& Shepherd, N. G. (1977) Biochem. J. 165, 375-383.

Theorell, H., \& Nygaard, A. P. (1954) Acta Chem. Scand. 8, 877-888.

Vargo, D., Pokora, A., Wang, S. W., \& Jorns, M. S. (1981) J. Biol. Chem. 256, 6027-6033.

Walsh, C. T., Schonbrunn, A., \& Abeles, R. H. (1971) J. Biol. Chem. 259, 6855-6866.

Wierenga, R. K., DeJong, R. J., Kalk, K. H., Hol, W. G. J., \& Drenth, J. (1979) J. Mol. Biol. 131, 55-73.

Yagi, K., \& Ozawa, T. (1962) Biochim. Biophys. Acta 56, $413-419$.

Yagi, K., Okamura, K., Naoi, M., Sugiura, N., \& Kotaki, A. (1967) Biochim. Biophys. Acta 146, 77-90.

Yagi, K., Nishikimi, M., Ohishi, N., \& Takai, A. (1970) FEBS Lett. 6, 22-24. 